\author{
Rafał Katamay \\ Wyższa Szkoła Zarządzania Ochroną Pracy w Katowicach \\ (D) https://orcid.org/0000-0003-0427-962X
}

\title{
Byt jako element natury w filozofii przedsokratejskiej
}

\section{Being as an Element of Nature in Presocratic Philosophy}

\begin{abstract}
The purpose of this article is to present an interpretation in the light of which one can read a characteristic aspect of the understanding of being in Presocratic philosophy. At the point of departure, Rafał Katamay emphasizes the idea of place within the etymology of the verb "to be"; generally, "to be" means "to be in the world". Next, he characterizes the world as existing implicitly (i.e., independently of the human mind) and having "a different plan", an order hidden behind phenomena. Attempts to understand this were called investigations into the nature (the nature of "things"), nature understood as the real foundation of the world and its active source, something that internally constitutes all objects of sensory perception and provides building materials, structures and laws of development. Against this background (which makes up the interpretive context), Katamay defines the understanding of a being as an element of nature in the sense of something identifiable in a distributive way, dependent, and always connected with self-sustaining nature. This element can be understood in two ways: 1) as an object accessible to the senses grasped together with the nature constituting it, e.g., a concrete tree; 2) as the internal nature, e.g., fire (Heraclitus) or the four elements (Empedocles), which sensual objects originate from or by which they are constituted.
\end{abstract}

Keywords: pre-Socratic philosophers, Ionic philosophy of nature, theory of being, ontology, metaphysics 
„W epoce pierwszego i decydującego rozkwitu filozofii zachodnioeuropejskiej, u Greków, w którego następstwie zaczęto prawdziwie zapytywać

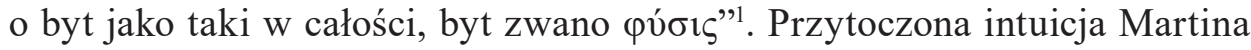
Heideggera wskazuje kierunek, w jakim będzie podążać główna myśl niniejszego artykułu. Jego celem jest przedstawienie interpretacji, która pozwoli na wydobycie charakterystycznego - zdaniem autora - „rysu” greckiej koncepcji bytu, tj. aspektu, jaki pojawił się już u początków filozofii greckiej, u jońskich filozofów przyrody, i później przewijał się w filozofii przedsokratejskiej.

Warto podkreślić, że interpretacja ta nie rości sobie prawa do kompletności odczytania rozumienia bytu u presokratyków, bo ta wymagałaby wydobycia pozostałych charakterystycznych aspektów tej filozofii, które można zrekonstruować, jeśli uwzględni się przede wszystkim myśl eleatów, a dalej także pitagorejczyków, a nawet sofistów, czy sięgnie po Corpus Hippocraticum. Nie chodzi tutaj również o historyczne ujęcie myśli filozofów czy prezentację szkół, ale o przedstawienie idei, która mimo wszystkich różnic między poszczególnymi myślicielami jest - zdaniem autora - dla nich charakterystyczna i pozwala na spójne odczytanie znaczenia czasownika „być” i jego nominalizacji w wielu tekstach tego okresu. A nawet dalej: idea ta, wzmocniona przede wszystkim przez Parmenidesa, może stanowić przyczynek do odczytania dojrzałych koncepcji Platona i Arystotelesa.

Artykuł bazuje $\mathrm{w}$ głównej mierze na tekstach oryginalnych ${ }^{2}$ oraz na wybranych interpretacjach badaczy myśli starożytnej. Tekst został podzielony na kilka części, które kolejno wprowadzają dany kontekst interpretacyjny (podrozdziały Miejsce, Świat, Natura), by następnie na jego tle przedstawić i podsumować aspekt greckiego rozumienia bytu jako elementu natury (podrozdziały Byt, Podsumowanie).

\footnotetext{
${ }^{1}$ M. Heidegger: Wprowadzenie do metafizyki. Przeł. R. Marszałek. Wydawnictwo KR, Warszawa 2000, s. 18.

2 Teksty greckie przytacza się za: Die Fragmente der Vorsokratiker. Eds. H. Diels, W. Kranz. Vol. 1-3. Weidmann, Zürich-Hildesheim 2014 (dalej jako DK); Aristotelis Physica. Ed. W.D. Ross. Oxford University Press, Oxford 1950; Perseus Digital Library. Ed. G.R. Crane. www.perseus.tufts.edu [dostęp: 23.07.2021]. Tłumaczenia polskie za: Arystoteles: Metafizyka. Tekst polski oprac. M.A. Krąpiec, A. Maryniarczyk na podstawie tłum. T. Żeleźnika. Redakcja Wydawnictw KUL, Lublin 1996; Arystoteles: Dzieła wszystkie. T. 2: Fizyka; O niebie; O powstawaniu i niszczeniu; Meteorologika; O świecie; Metafizyka. Przeł. K. Leśniak. Państwowe Wydawnictwo Naukowe, Warszawa 1990; M. Wesoły: Heraklit $w$ świetle najnowszych badań. „Studia Filozoficzne” 1989, nr 7-8, s. 33-47. Przekład, jeśli nie jest podane inaczej, własny, również komentarzy obcojęzycznych.
} 


\section{Miejsce}

Byt to po grecku $\tau$ ò őv. Słowo őv (jońskie \&̇óv) jest imiesłowem czasu

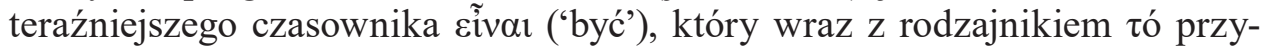
biera formę rzeczownika odsłownego tò őv. Wierny jego przekład brzmiałby „(to, określone) będące”, ale - by uniknąć w języku polskim pewnej sztuczności - używany będzie termin „byt”. Dopóki bowiem nie dysponuje się jego rozumieniem, dopóty każdy przekład niewiele będzie mówił.

Etymologii greckiego słowa „byt” trzeba szukać w tonącym we mgle historii rdzeniu *es. Językoznawcy jako jego pierwotne znaczenia podają zazwyczaj 'oddychać', 'żyć', 'być'3, 'być obecnym (tutaj, wśród żyjących)', 'pozostawać w stanie (czegoś) $)^{4}$, a nawet 'posiadać istnienie', 'znajdować się w rzeczywistości's lub też uznają ten rdzeń za bezbarwny (colorness) znaczeniowo ${ }^{6}$. Nieokreśloność znaczeniowa jest charakterystyczna dla łącznika (copula), ale nie - zdaniem Erica Havelocka - dla czasownika „być”, którym posługuje się wczesna greka mówiona, greka Homera i Hezjoda. W Iliadzie różne formy czasownika „być” służą wprowadzeniu postaci na scenę („,Był

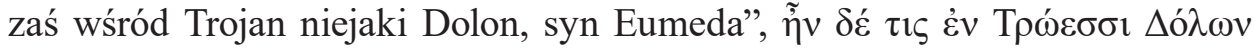

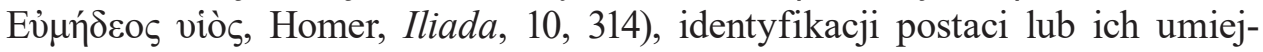

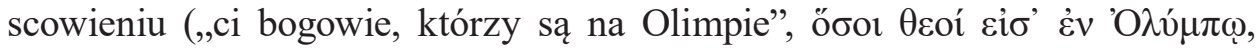

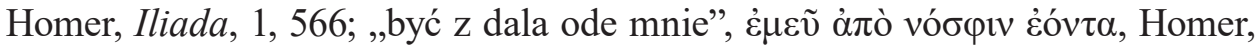
Iliada, 1, 541), określają pozycję, status postaci („,który teraz twierdzi, że jest

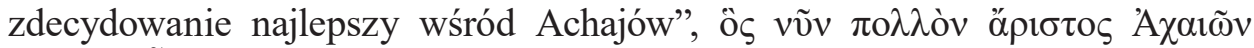

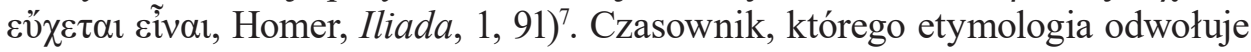

${ }^{3}$ G. Curtius: Grundzüge der Griechische Etymologie. Teubner, Leipzig 1869, s. 337.

${ }^{4}$ Ch.H. Kahn: The Verb „Be” in Ancient Greek. D. Reidel Publishing Company, Dordrecht-Boston 1973, s. 375-377.

${ }^{5}$ E. Benveniste: Problèmes de linguistique générale. Vol. 1. Gallimard, Paris 1966, s. 188.

${ }^{6}$ C.D. Buck: A Dictionary of Selected Synonyms in the Principal Indo-European Languages. A Contribution to the History of Ideas. University of Chicago Press, Chicago 1949, s. 635.

${ }^{7}$ Przykłady na podstawie: E.A. Havelock: The Early History of the Verb „to Be”. W: Idem: The Greek Concept of Justice. From Its Shadow in Homer to Its Substance in Plato. Harvard University Press, Cambridge 1978, s. 233-248, 356-357. Havelock charakteryzuje czasownik „być” w literaturze przedfilozoficznej przeciwnie niż Charles H. Kahn, którego zdaniem „być” występuje w centralnej i najczęstszej funkcji łącznika. W umysłowości archaicznej - twierdzi Havelock, ilustrując to szeregiem przykładów - wyrażenie predykacji w języku obywa się bez łącznika, poprzez zestawienie słów; nie dodaje się słówka „być”, by nie wprowadzać obecności. Na przykład: „bo wiele (»rzeczy« jest/znajduje się) między

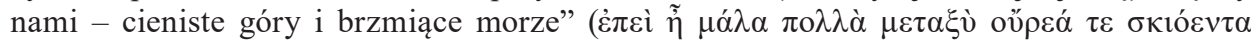

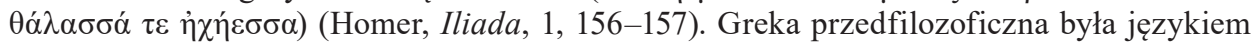


się do życia i miejsca jego przebiegu, niesie z sobą ideę lokacji (choć nie tylko ${ }^{8}$ ), stąd „być” znaczy generalnie 'znajdować się gdzieś, mieć miejsce'. Domyślnym miejscem czy kontekstem, w jakim się coś znajduje, jest realny świat, dlatego „być” to 'znajdować się w świecie', przede wszystkim pośród żyjących ludzi i zwierząt oraz aktualnie dostępnych przedmiotów. Domyślny kontekst jest zazwyczaj „zwinięty” i mamy po prostu „być” czy „będące” jako wynik pewnego rodzaju abstrakcji: 'żyć' $\rightarrow$ 'znajdować się pośród żywych' $\rightarrow$ 'znajdować się gdzieś w świecie' $\rightarrow$ 'znajdować się gdzieś' $\rightarrow$ 'być' (gdzieś).

Warto zwrócić uwagę na jeszcze dwa aspekty semantyczne czasownika „być”, z których pierwszy również jest związany z ideą miejsca. Należy on do rodziny czasowników statycznych, znajdujących się w opozycji do rodziny czasowników dynamicznych ze „stawać się” (literalnie 'rodzić się')

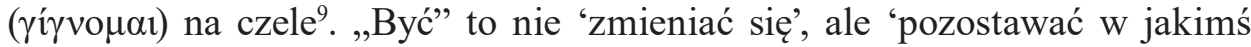
stałym stanie i miejscu'. Drugą istotną opozycją konstytuującą „być” jest

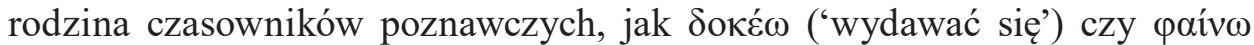
('ukazywać się, 'wyglądać się') nie mieć miejsce niezależne od czyjegoś poznania'.

Idea miejsca wiąże się też z ideą prawdy pojętą jako 'tak się rzeczy mają',

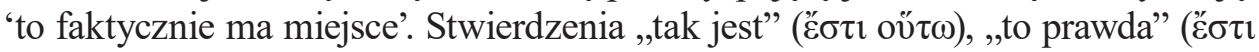
$\tau \alpha \tilde{\tau} \tau \alpha)$ oznaczają, że to, co zostało powiedziane, faktycznie zaszło lub zachodzi

mówionym, jej słuchacze byli przygotowani do zapamiętywania treści ze słuchu, stąd عĩvoı nie był bezbarwną monosylabą, jak to jest w wielu współczesnych językach. Choć eĩvoı często w pierwszym kontakcie z tekstem może być interpretowane właśnie jako łącznik, po głębszej analizie i uwzględnieniu kontekstu, w jakim występuje, okazuje się, że wskazuje lokalizację, wyraża obecność lub stan, „być” to więc 'być obecnym', 'stać', 'pozostawać'.

${ }^{8}$ Wyróżnienie tej idei następuje nie ze względu na częstotliwość jej występowania czy istotny sens semantyczny bardziej lub mniej uwidaczniający się w różnych użyciach byłaby to wtedy hipoteza, która wymagałaby przeprowadzenia osobnych badań. Idea lokacji, którą można odnaleźć w pierwotnych znaczeniach i użyciach czasownika „być”, stanowi tu dogodny kontekst interpretacyjny, w świetle którego (i w powiązaniu z dalszą charakterystyką) odczytanie wyróżnionego aspektu filozoficznego rozumienia bytu staje się jaśniejsze.

9 Zob. J. Lyons: Wstęp do językoznawstwa. Przeł. K. Bogacki. Państwowe Wydawnictwo Naukowe, Warszawa 1975, s. 357-358; Ch.H. Kahn: The Verb „Be”..., s. 194-227, 388-389.

${ }^{10}$ Zob. Ch.H. Kahn: The Verb „Be”..., s. 392-394. Kahn pisze również o trójstronnym systemie kontrastów „być - stawać się - stawiać/robić” (be - become - put/make) na wyra-

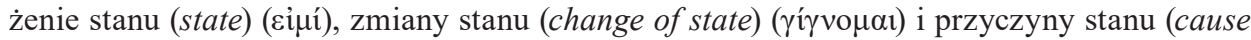
of state) $(\tau i \dot{\theta} \mu \mathrm{u})$. Dodaje, że chyba tylko przez przypadek filozofowie greccy nie zrobili użytku z opozycji pomiędzy Byciem a Powoływaniem (-do-bycia) - użytku porównywalnego do tego, jaki zrobili z opozycji między Byciem a Stawaniem się i Byciem a Wydawaniem się. Ibidem, s. 390, 392, 394. „Dopiero w czasach chrześcijaństwa i islamu, pod wpływem biblijnej religii, różnica między wiecznym a stworzonym bytem lub pomiędzy bez przyczyny a mającym przyczynę istnieniem [uncaused and caused existence] została opracowana

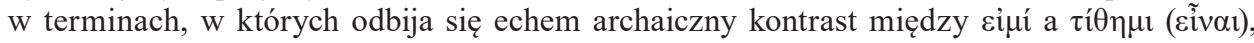
między Byciem [Being] a Powoływaniem-do-bycia [Making-to-be]”. Ibidem, s. 394. 
w świecie, w rzeczywistości, w której „rzeczy” tak się mają. Odesłanie więc do istniejącego kontekstu świata, umiejscowienie czegoś w nim jest jednoznaczne $\mathrm{z}$ potwierdzeniem prawdziwości, $\mathrm{w}$ przeciwieństwie do fikcji, pomyłki czy

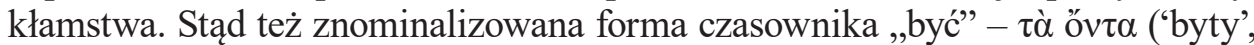
'te będące') może oznaczać 'prawdę' lub 'to, co miało miejsce'11.

Ideę umiejscawiania $\mathrm{w}$ świecie możemy powiązać też $\mathrm{z}$ modelem wyjaśniającym, który pojawił się jako pierwszy właśnie w kontekście literatury przedfilozoficznej - z modelem genealogicznym (genetycznym) ${ }^{12}$. Wyjaśnić coś to podać tego genealogię, wyjaśnić, ,co powstało jako pierwsze” (ö $\tau 1$

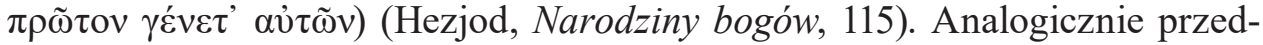
stawić i poznać kogoś to umiejscowić go gdzieś, na przykład w rodzie (Dolon, syn Eumeda), w mieście (Tales z Miletu). Choć aspekt genetyczny $\mathrm{w}$ sensie pochodzenia nie był obecny w pierwotnym znaczeniu czasownika „być”, na które tu wskazano, to dla genezy i bycia wspólna jest idea miejsca, w sensie lokowania czegoś w jakimś kontekście wyjaśniającym, a jednocześnie podstawowym. Coś, co jest lub powstało, ma swoje miejsce w czymś bardziej pierwotnym, w którym jest obecne lub z którego się wywodzi. „Być” to 'mieć miejsce w czymś bardziej pierwotnym'; w ujęciu genetycznym mieć takie miejsce dzięki swojemu pochodzeniu, dlatego, że ma się korzenie, pochodzi się z jakiejś rodziny, jakiegoś miasta. $\mathrm{W}$ tym sensie idea miejsca i pochodzenia łączą się z sobą ${ }^{13}$. Model genetyczny, zgodnie z interpretacją Arystotelesa (Metafizyka 983b), będzie jeszcze funkcjonował u pierwszych filozofów, na przykład Talesa czy Anaksymandra, bo wyjaśnić byty to podać ich pochodzenie, wskazać ich źródło (⿳亠丷厂甲价, tak jak wcześniej ród czy miasto pochodzenia.

Podsumowując, można powiedzieć, że idea zajmowania określonego miejsca $\mathrm{w}$ świecie, lokowania czegoś w nim jest jednym z pierwotnych rysów znaczeniowych czasownika „być”. „Być” to w konsekwencji 'znajdować się w świecie'. Bycie oznacza powiązanie danego przedmiotu lub jego cech

${ }^{11}$ Zob. ibidem, s. 334, 350 .

${ }_{12}$ Zob. G.S. Kirk, J.E. Raven, M. Schofield: Filozofia przedsokratejska. Studium krytyczne z wybranymi tekstami. Przeł. J. Lang. Wydawnictwo Naukowe PWN-Axis, Warszawa 1999, s. 82; A. Gawroński: Rewolucja lingwistyczna presokratyków. Język a rzeczywistość (11). „Znak” 1992, nr 440 (1), s. 77-78; M. Moravcsik: Her Heraclitean Concepts and Explanations. W: Language and Thought in Early Greek Philosophy. Ed. K. Robb. The Hegeler Institute, La Salle, Illinois 1983, s. 135.

${ }^{13} \mathrm{Na}$ marginesie można tu zestawić aspekt genetyczny widoczny w pierwotnym znaczeniu łacińskiego existere ('istnieć'), gdzie sistere ma między innymi znaczenie 'postawić', 'stanąć, 'znajdować się', 'mieć miejsce', 'trwać', a wraz z genetycznym przedrostkiem ex-sistere 'zjawiać się, 'ukazywać się', 'wywodzić się z', 'powstać', 'wejść w życie'. Zob. E. Gilson: Byt $i$ istota. Przeł. P. Lubicz, J. Nowak. Instytut Wydawniczy PAX, Warszawa 1963, s. 13. 
z domyślnym kontekstem świata, z pierwotnym i ze stałym miejscem. „Być” to 'mieć poza umysłem określone miejsce lub pozycję w świecie', 'stale przebywać', 'być obecnym gdzieś' lub 'pozostawać gdzieś'.

\section{Świat}

Można zapytać, jak był rozumiany świat jako pierwotny kontekst, do którego czasownik „być” implicite się odnosił. Trzeba przede wszystkim zauważyć, że świat ten był określony już przedrefleksyjnie: chodzi o świadomość drugiego ,planu gry" - świat, w jakim zrodziła się filozofia, był światem postrzeganym dwuplanowo. To, co niezrozumiałe dla człowieka, było zrozumiałe dla boga ${ }^{14}$. Aby rozumieć pierwszy ,plan gry”, dostępny zmysłami świat, w którym rozgrywa się ludzkie życie, należy odsłonić „drugi plan”, dziedzinę boskich potęg, sił i wpływów. Starożytny Grek mieszkał i poruszał się w naturze „,pełnej bogów”: dusza była zmieszana z całością świata, a wszystko było pełne bogów - miał twierdzić Tales (DK, 11 A 22). Boskość świata nie oznaczała jakiejś konkretnej jej postaci chronionej kanonem ksiąg, głoszonej najpierw przez proroków i założycieli religii, a następnie przez kapłanów. Była cechą strukturalną, integralną tego świata, przenikała go, stanowiła duszę każdego żywiołu ${ }^{15}$. Bogowie byli związani z pierwotnymi siłami, jak morze czy ziemia, i podlegali nadrzędnemu prawu rządzącemu losami i porządkiem świata, a za tym prawem stały przeznaczenie $(\mu \circ \tilde{\rho} \rho \alpha)$ i konieczność $(\tau o ̀ ~ \chi \rho \varepsilon \omega ́ v)^{16}$. Bogowie nie byli poza światem, więc go nie

14 „Przekonanie co do tego, iż Moce silniejsze, potężniejsze od ludzi istnieją i należy je czcić, było w Grecji powszechne. Pierwsze i najważniejsze z »niepisanych praw«, przekazywanych z pokolenia na pokolenie, o których wzmiankują źródła pisane, stanowiło:

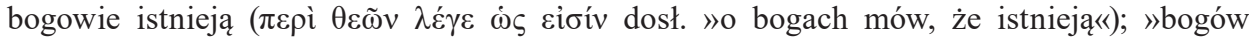

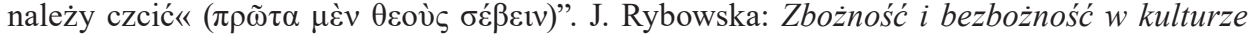
Greków. Wydawnictwo Uniwersytetu Łódzkiego, Łódź 2017, s. 21.

${ }^{15}$ Zob. T. Zieliński: Religia starożytnej Grecji. Zarys ogólny. Religia hellenizmu. Zakład Narodowy im. Ossolińskich - Wydawnictwo, Wrocław 1991, s. 37-38. „Podłożem - może najgłębszym - uczucia religijnego starożytnego Greka była świadomość tajemniczego życia otaczającej go natury. I nie tylko życia, lecz i uduchowienia, i nie tylko uduchowienia, lecz i boskości. [...] Dla świadomości Greka martwa natura nie istniała; natura cała była życiem, cała - duchem, cała - bóstwem". Ibidem, s. 42.

${ }^{16}$ Zob. Anaksymander, DK 12 B 1. Zob. też D. Kubok: Problem apeiron i peras $w$ filozofii przedsokratejskiej. Uniwersytet Śląski w Katowicach, Instytut Filozofii, Katowice 1998, s. 11, 36. 
stworzyli, byli w świecie. Nie był to jednak panteizm, ale świadomość, że świat nie jest ,płaski”, lecz wielowymiarowy. Powiązanie bogów z żywiołami i prawami natury stanowiło dla filozofii, kierującej się rozumem, dobry punkt wyjścia, łatwo bowiem można było porzucić spersonifikowane postacie ludzkich bogów, by przejść do pierwiastków i sił natury oraz ich odwiecznego prawa.

Uniezależnienie się od wyjaśniania mitycznego nie musiało oznaczać oswobodzenia się ze szczególnej postawy duchowej - świadomości drugiej strony bezpośredniego doświadczenia ${ }^{17}$. Przeciwnie, postawa ta, nie determinując filozoficznych rozważań ${ }^{18}$, pobudzała je do ciągłego wykraczania poza dane bezpośredniego doświadczenia i poszukiwania tego, co je wyjaśnia: niezależnych od człowieka zasad i przyczyn, które - jak wcześniej bogowie - wszystkim rządzą. Filozofia grecka, pomimo że poszła jeszcze inną, pośrednią drogą, pomiędzy factum świata, którego się nie rozumie, a dictum mitu, który podaje do wierzenia, nigdy nie zerwała związków ani z jednym, ani z drugim. Teoria $(\theta \varepsilon \omega \rho i ́ \alpha)$ - czyli rozumowy ogląd świata do której dążyła filozofia, była formą rozumowej kontemplacji, oglądaniem „drugiego planu” świata, boskiego widowiska ${ }^{19}$.

Pierwszym i chyba najważniejszym w kulturze greckiej objawieniem się tego, co boskie, w namacalnej i odsłoniętej postaci było piękno. Władców oglądanego spektaklu, bogów przedstawiono w postaci posągów. To one wyznaczyły jeden z najmocniej oddziałujących kanonów piękna w kulturze europejskiej - wyrazistą, harmonijną i geometryczną formę, opartą na proporcji i symetrii. Ten kanon i jednocześnie wyraz ducha greckiego z pewnością odcisnął swoje piętno na wielu koncepcjach filozoficznych,

17 „Filozoficzna koncepcja kosmosu - podkreśla Werner Jaeger - oznacza niewątpliwie zerwanie z potocznymi wyobrażeniami religijnymi, ale to zerwanie prowadziło tylko do nowego, głębszego poglądu na boskość bytu wśród grozy przemijania i zniszczenia". W. Jaeger: Paideia. Formowanie człowieka greckiego. Przeł. M. Plezia, H. Bednarek. Fundacja Aletheia, Warszawa 2001, s. 239. „Problem rzeczywistości [reality] - pisze John Burnet - to faktycznie problem relacji człowieka do niej, która od razu przenosi nas poza czystą naukę. [...] Każdemu, kto próbował zrozumieć greckich filozofów, propozycja traktowania ich jako »intelektualistów« musi wydawać się śmieszna. Jest bowiem odwrotnie, grecka filozofia jest oparta na wierze, że rzeczywistość jest boska i że jedyna rzecz potrzebna duszy, która jest pokrewna boskości, to wejść z nią [rzeczywistością - R.K.] we wspólnotę". J. Burnet: Greek Philosophy. Thales to Plato. MacMillan, London 1924, s. 12.

${ }^{18}$ Zob. G.E.R. Lloyd: Nauka grecka od Talesa do Arystotelesa. Przeł. J. Lesiński. Prószyński i S-ka, Warszawa 1998, s. 17.

${ }_{19}$ Por. K. Albert: O Platońskim pojęciu filozofii. Przeł. J. Drewnowski. Polska

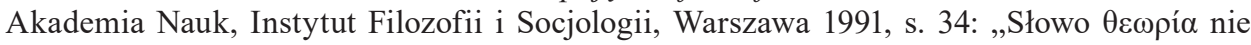
wywodzi się [...] od $\theta \varepsilon ́ \alpha$ (widowisko) i ópõv (zachowywać, doglądać, postrzegać, widzieć), lecz od $\theta \varepsilon o ́ \varsigma$ (bóg) i ópõv. Nie znaczy więc: »oglądać widowisko«, lecz: »boga (tzn. jego wolę, jego polecenia) zachowywać i chronić«". 
w szczególności pitagorejczyków, Platona czy Arystotelesa oraz na samej koncepcji bytu jako „ukształtowanego materiału. Te rzeczy są prawdziwe, których budową można się zachwycać, których formę, relacje i strukturę można opisać [...]. Oglądanie rzeczy jest dotykaniem w tym samym czasie ich formy, która definiuje obiekt jako byt" ${ }^{\prime 20}$.

Piękno, którego namacalną postacią była forma mająca odpowiednie proporcje, nie znajdowało się $\mathrm{w}$ oku patrzącego, ale jak bogowie ${ }^{21}$ przychodziło z zewnątrz, było wcześniej niż człowiek zdołał je odsłonić i upamiętnić w kamieniu. Budziło zdumienie, podziw, zachwyt, tak jak wcześniej bogowie, bo zazwyczaj u Homera to, co potężniejsze od człowieka, mogło powodować taki $\operatorname{stan}^{22}$. Analogicznie do tego, świat, który filozof próbował zrozumieć, posiadał w sobie wcześniejszy od poznania logos, który mógł być odsłonięty w toku dociekania filozoficznego. Był to więc świat obiektywny, niezależny od człowieka, a człowiek stanowił część tej wielkiej całości, mógł poznawać świat, ale był od niego zależny. Wyrazem takiego podejścia jest fragment

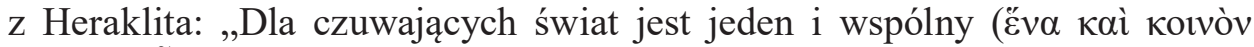

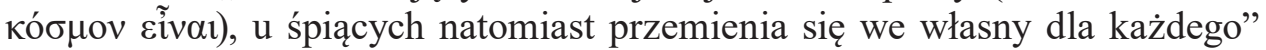
(Heraklit, DK 22 B 89, przel. M. Wesoły) ${ }^{23}$.

${ }^{20}$ R. Bultmann: Zur Geschichte der Lichtsymbolik im Altertum. „Philologus - Zeitschrift für antike Literatur und ihre Rezeption" 1948, vol. 97, s. 17. Podobnie W.F. Otto: Die Götter Griechenlands. Das Bild des Göttlichen im Spiegel des griechischen Geistes. Friedrich Cohen, Bonn 1929, s. 10: bycie (das Sein) „objawia się poprzez formę”.

${ }^{21}$ Bardziej zrozumiemy wiarę Greków, jeśli założymy, że „treścią wiary był realny byt istotowy [Wesenhaftes], jakaś żywa całość”, bo jak argumentuje Wilamowitz, „Żaden człowiek nie modli się przecież do konstruktu myślowego". W.F. Otto: Dionizos. Mit i kult. Przeł. J. Korpanty. Wydawnictwo Naukowe Sub Lupa, Warszawa 2020, s. 27-28, 33, 41-43.

${ }^{22}$ H. Arendt: Myślenie. Przeł. H. Buczyńska-Garewicz. Spółdzielnia Wydawnicza „Czytelnik”, Warszawa 1991, s. 199. Zdziwienie pełne pochwały dotyczy „nie konkretnego zjawiska ani sumy rzeczy w świecie, lecz harmonii i porządku tkwiącego za nimi, który sam jest niewidzialny, ale zjawiające się rzeczy są jego świadectwem. »Zjawiska są błyskiem niewidzialnego«, jak powiadał Anaksagoras. Filozofia zaczyna się wraz ze świadomością niewidzialnego harmonijnego porządku świata, który przejawia się w rzeczach widzialnych, jak gdyby były one przeźroczyste. [...] Innym dawnym słowem na to, co niewidzialne w zjawisku, jest physis, natura, która wedle Greków była całością wszystkich rzeczy nie będących wytworami ludzkimi i nie stworzonych siłą boską, lecz istniejących same przez się; o tej to physis Heraklit powiadał, że »lubi ukrywać się«, właśnie poza zjawiskami". Ibidem, s. 200-201.

${ }^{23}$ Cyt. za: M. Wesoły: Heraklit $w$ świetle najnowszych badań..., s. 40. Stefan Swieżawski nazywa tę postawę obiektywizmem, który cechował starożytność oraz średniowiecze. Postawa ta polega na świadomości „,prawdy, że człowiek zależny jest od tego, co go otacza, od rzeczywistości, którą bada i odkrywa, ale której nie ustanawia". S. Swieżawski: Byt. Zagadnienia metafizyki tomistycznej. Wydawnictwo Znak, Kraków 1999, s. 38. Zob. też E. Schrödinger: Przyroda i Grecy. Nauki przyrodnicze i humanistyczne. Przeł. K. Napiórkowski. Wydawnictwo IFiS PAN, Warszawa 2017, s. 52, 67-68, 
Warto - przy założeniu, że świat jest obiektywny - podkreślić również, że jego istnienie nie zależy od niczego. Można nawet z dość dużą pewnością twierdzić, że to, iż świat jest czymś realnie istniejącym i nie powstał z niczego, było niewypowiedzianym założeniem refleksji pierwszych i kolejnych filozofów starożytnych ${ }^{24}$. Podkreślał to również Heraklit: „tego kosmosu

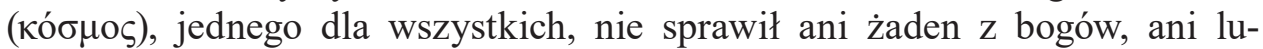
dzi, lecz był on zawsze i jest, i będzie wiecznie żyjącym ogniem ( $\dot{\alpha} \lambda \lambda^{\prime} \tilde{\eta} v$

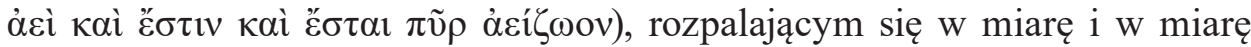
gasnącym" (Heraklit, DK, 22 B 30, przeł. M. Wesoły) ${ }^{25}$. To, czym jest ten wzbudzający podziw i zdumienie, boski i piękny, samodzielnie istniejący świat, było dopiero tematem dociekań. Gdybyśmy najtrafniej chcieli nazwać przedmiot tego filozoficznego poszukiwania „,czym jest”, moglibyśmy użyć

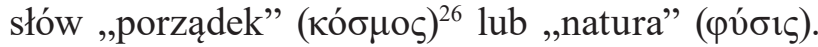

$\mathrm{Na}$ podstawie tego, co już napisano, można wyróżnić kilka cech charakterystycznych świata, do którego czasownik „być” i jego nominalizacje będą odsyłać. Po pierwsze, świat jest czymś obiektywnie i samodzielnie istniejącym wobec człowieka, człowiek w żaden sposób nie ustanawia świata, świat stanowi coś niezależnego, czego człowiek jest tylko częścią. Po drugie, świat to nie tylko zjawiska, czyli przedmioty zmysłowo dostępne, ale przede wszystkim ich druga strona, ukryta za nimi podstawa. Oznaczała ona pewną pierwotnie mitologiczną boską potęgę, która rządzi wszystkim, potęgę, która w refleksji filozoficznej zaczęła być racjonalnie badana i ujawniana za pomocą słów oraz teorii. Boskość była tu pewnym gwarantem obiektywnej niezależności i pełni, do której człowiek dążył, uświadamiała istnienie niezależnego, trwałego „arbitra”, mogącego rozstrzygnąć każdy spór filozoficzny - prawdy leżącej po stronie rzeczywistości. Po trzecie, świat przejawiał się $\mathrm{W}$ swej harmonijnej budowie, formie oraz stałych prawach i prawidłowościach nim rządzących. Można było więc podziwiać jego obiektywne piękno oraz poznawać jego porządek, warto podkreślić jeszcze raz,

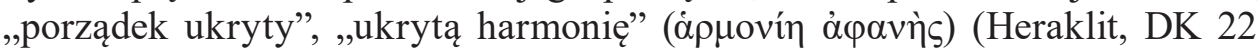
B 54), która mogła być odczytywana dopiero w rozumowym oglądzie.

84-87. Oczywiście z tą postawą będą dyskutować sofiści, jak Protagoras (autor zasady homo mensura).

${ }^{24}$ „Filozofia starożytna nie przejmowała się takimi pytaniami, jak to, czy naprawdę istnieje zewnętrzny świat. Jego istnienie jako całkowicie niezależne od myślenia człowieka było zawsze główną presupozycją filozofów starożytnych". L.M. de Rijk: Plato’s Sophist. A Philosophical Commentary. North-Holland Publishing Company, Amsterdam 1986, s. 75.

${ }^{25}$ Cyt. za: M. Wesoły: Heraklit w świetle najnowszych badań..., s. 44.

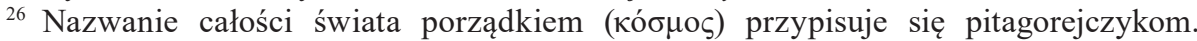
G. Reale: Historia filozofii starożytnej. T. 1: Od początków do Sokratesa. Przeł. E.I. Zieliński. Redakcja Wydawnictw KUL, Lublin 1994, s. 116-117. 
Człowiek w filozofii greckiej przyjmował charakterystyczną postawę widza, który uczestniczył $\mathrm{w}$ boskim spektaklu świata, postrzegając go od razu dwuplanowo: jako dostępny zmysłami świat oraz ujawniający się poprzez zmysłowość porządek. Oczywiście to ten drugi plan był źródłem zdziwienia i zachwytu, dlatego też stał się centralnym tematem pierwszych

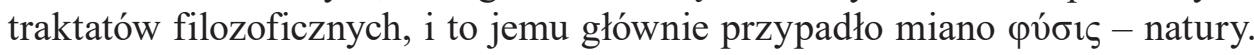

\section{Natura}

Etymologicznie $\varphi v ́ \sigma ı \varsigma$ oznacza biologiczny proces rodzenia się, rośnięcia: $\varphi v ́ \omega, ~ \varphi v ́ \varepsilon ı v$ to 'wydawać', 'wypuszczać', 'rodzić', 'rosnąć, 'powstawać'.

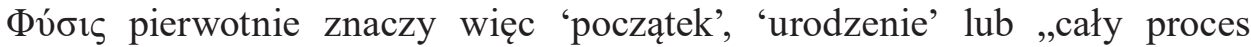
wzrostu rzeczy od urodzenia do dojrzałości”27, dokonujący się sam z siebie,

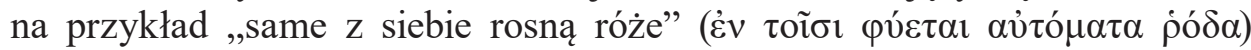
(Herodot, Dzieje VIII, 138, 2) ${ }^{28}$. W literaturze przedfilozoficznej spotykamy to słowo w zasadzie tylko raz, u Homera: Hermes, dając wyrwaną z ziemi roślinę, „pokazał [...] jej naturę. Korzenie jej były czarne, kwiat biały

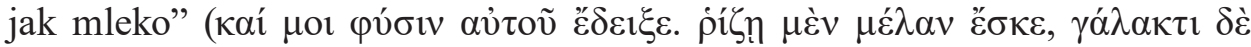

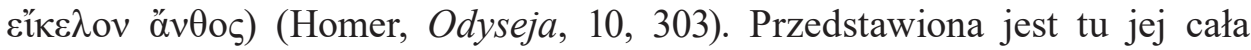
postać i charakterystyka, przejawiająca się rośnięciem od korzenia poprzez kwiat. Natura to jednak nie „zewnętrzna charakterystyka” rośliny ${ }^{29}$, ale jej „ukryta moc" 30 , czyli wewnętrzny proces, który zaczyna się od ukrytego głęboko w ziemi ciemnego korzenia, a kończy się rozkwitem i pełnym ujawnieniem mleczno-białej postaci ${ }^{31}$. Pokazać naturę rośliny to pokazać ją całą od korzenia po kwiat.

27 G. Naddaf: The Greek Concept of Nature. State University of New York Press, New York 2005, s. 12. Zob. też Arystoteles, Metafizyka 1014b16-17.

${ }_{28}$ Zob. J. Domański: Metafizyka Arystotelesowa i fizyka pierwszych filozofów. (Uwagi o nazwie, pojęciu i przedmiocie metafizyki). „Archiwum Historii Filozofii i Myśli Społecznej” 1991, nr 36, s. 5-24. Pobrano z: http://old.archidei.ifispan.pl/pdf/41_ahf0001_36_domanski. pdf [12.06.2021], s. 20 .

${ }^{29}$ Zob. J.W. Beardslee: The Use of PHYSIS in Fifth-Century Greek Literature. The University of Chicago Press, Chicago 1918, s. 6.

${ }^{30}$ A. Heubeck, S. West, J.B. Hainsworth: A Commentary on Homer's Odyssey. Vol. 2. Clarendon Press, Oxford 1988, s. 60.

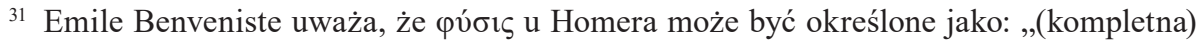
realizacja stawania się”, ,natura jako to, co jest zrealizowane wraz ze wszystkimi jej właś- 
Wraz z pojawieniem się refleksji filozoficznej słowo „natura” zaczęło odgrywać ważną rolę, służyło wyjaśnianiu świata. Dzieła pierwszych myślicieli, filozofów jońskich, eleatów czy pluralistów, zostały opatrzone tytułem $O$ naturze ( $\pi \varepsilon \rho i ̀ ~ \varphi v ́ \sigma \varepsilon \omega \varsigma)$ najprawdopodobniej później, choć niektórzy badacze uważają, że już Parmenides lub Empedokles posługiwali się słowem "natura" ${ }^{2}$. Najpewniej było ono jednak znane pierwszym filozofom i miało wskazywać na właściwy przedmiot wyjaśniania świata i jego zjawisk; ilustrować to może fragment z Heraklita: „zgodnie z ich naturą rozróżniając

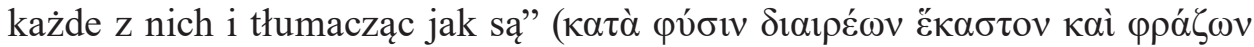

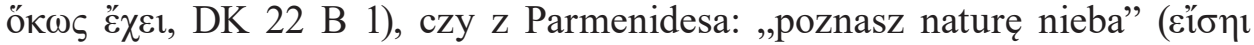

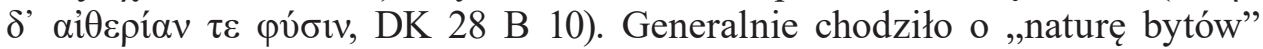
( są odbierane zmysłami ${ }^{33}$. Naturę możemy więc traktować jako coś, co wyjaśnia coś innego, dlatego słowo to wymaga drugiego, w dopełniaczu: natura czegoś, natura „rzeczy”. To natura determinuje owe „rzeczy” do tego, czym są, stąd poznanie jej byłoby wystarczającym ich wyjaśnieniem. Nie jest to jednak jeszcze ogólne pojęcie, wynikłe $\mathrm{z}$ aktywności abstrahującego umysłu; trzeba ją pojmować przez pryzmat samych przedmiotów, jak desygnat, do którego odsyła nazwa „natura”, jak esencję, która pozostaje - mówiąc nieładnie - po ich ,wyciśnięciu”, jak podstawową właściwość stale je determinującą, z której jak z korzenia wyrastają jej różnorakie zmysłowe formy (zob. Arystoteles, Fizyka 193a9-17). Oczywiście woda w rozumieniu Talesa w odmienny sposób wyjaśniała świat niż kolejne propozycje, Anaksymandra czy Anaksymenesa. Ważne jest tu jednak, że wyjaśnienie to dążyło do uczynienia z niej „prażywiołu”, z którego powstają wszystkie „rzeczy”, że była myślana poprzez swój desygnat, który nie tyle odnosił się do wód i wszelkiej zmysłowej wilgoci, ile do natury „płynącej” w tych wszystkich zjawiskach. Uogólniając, można powiedzieć, że dostępna zmysłami woda była zewnętrznym i najbardziej reprezentatywnym przejawem natury, do której można zredukować i za pomoca której w pełni wyjaśnić świat zmysłowy.

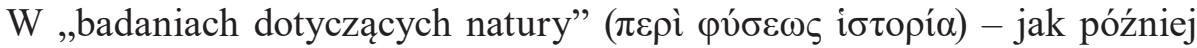
określano wysiłki pierwszych filozofów - nie rozumiano jej więc jako zewnętrznej przyrody, słowo „natura” nie funkcjonowało jako kolektywna nazwa obejmująca swym zakresem wszystkie naturalne przedmioty. Natura traktowana była bardziej jako uzewnętrznienie pewnej wewnętrznej kon-

ciwościami”. E. Benveniste: Noms d'agent et noms d'action en indo-européen. Klincksieck, Paris 1948, s. 78-79.

${ }^{32}$ Zob. G. Naddaf: The Greek Concept of Nature..., s. 16-17.

${ }^{33}$ Trzeba podkreślić, że słowo „rzecz” jest tu i w dalszej części tekstu użyte neutralnie, bez reifikacyjnych konotacji, analogicznie do słowa „przedmiot”, z tym że z fizycznym czy zjawiskowym zabarwieniem. 
stytucji, która ogarnia i przenika wszystko albo której wszystko jest przejawem $^{34}$. Dlatego też podjęto poszukiwania natury ( próbowano dojść do tego, co faktycznie wewnątrz przedmiotów powoduje ich takie, a nie inne zachowania ${ }^{35}$. „Natura, która według Heraklita lubi się skrywać” (

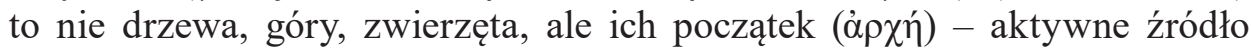
i podłoże, z którego powstają, które je nieustannie rodzi i do którego powracają, oraz zasada, która nimi rządzi i ustala ich prawa rozwoju ${ }^{36}$. Heraklit wskazuje, że trzeba sięgnąć poza dane zmysłowe, by „zrozumieć myśl, która

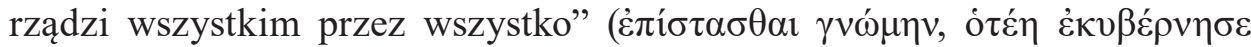
$\pi \alpha ́ v \tau \alpha \delta$ ì̀ $\pi \alpha ́ v \tau \omega v)$ (DK 22 B 41).

Pierwsi filozofowie stworzyli różne modele wyjaśniania natury: genetyczny (jońscy filozofowie przyrody), strukturalny (pitagorejczycy), ontyczny (eleaci), składnikowy (pluraliści) - oraz teorie natury: określano pratworzywo (budulec, podłoże) przedmiotów zmysłowych (Tales, Anaksymenes), ich strukturę (układ) (pitagorejczycy), wskazywano na niezmienny i stały „rdzeń” natury, jej bycie (Parmenides) czy ustalano pierwotne elementy ( $\tau \dot{\alpha} \pi \rho \tilde{\omega} \tau \alpha$; $\tau \grave{\alpha} \sigma \tau$ oı $\chi \tilde{\imath} \alpha)$ (Empedokles, Anaksagoras) lub atomy (Demokryt) (składniki), z których są zrobione przedmioty oraz prawa nimi rządzące. Natura stanowiła więc realną konstytucję, która łączyła w sobie różne aspekty: tworzywo, strukturę, prawo oraz - co warto podkreślić - zasadę ruchu i działania ${ }^{37}$.

${ }^{34}$ Dla jońskich „fizyków” - pisał Jean-Pierre Vernant - „nie ma niczego, co nie byłoby naturą, physis. Ludzie, bóstwo i świat tworzą uniwersum zjednoczone, homogeniczne, jednoplanowe: są częściami czy też aspektami jednej i tej samej physis, która wszędzie uruchamia te same siły, ujawnia tę samą życiową moc". J.P. Vernant: Źródła myśli greckiej. Przeł. J. Szacki. Wydawnictwo słowo / obraz terytoria, Gdańsk 1996, s. 122. Zgodnie $\mathrm{z}$ przedstawioną interpretacją nie ma $\mathrm{w}$ świecie niczego, co by naturę przekraczało (było nadnaturalne), niemniej zmysłowa warstwa to tylko jej zewnętrzny przejaw. Słowo ,jednoplanowe" w przedstawionym cytacie ukazuje zatarcie różnicy między planem zewnętrznych zjawisk a ich wewnętrzną naturą.

${ }^{35}$ Zob. R.G. Collingwood: The Idea of the Nature. Clarendon Press, Oxford 1945, s. 44-45; G. Reale: Historia filozofii starożytnej..., s. 77.

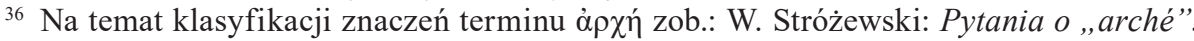
W: Idem: Istnienie i sens. Wydawnictwo Znak, Kraków 1994, s. 7-48.

${ }^{37}$ Zob. Arystoteles, Fizyka 192b-193a; Metafizyka 1014b-1015a; Platon, Prawa, 891c, 892c. Charles H. Kahn, powołując się na pełne przykładów badania, które przeprowadził

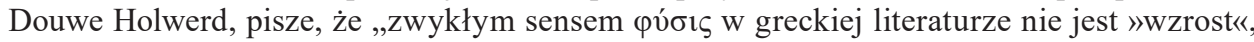
ale »forma, charakter, natura (danej rzeczy)«”. Dodaje, że „Pierwsi filozofowie starali się zrozumieć "naturę« rzeczy przez odkrywanie, z jakiego źródła i w jaki sposób doszło do bycia to, co jest". Ch.H. Kahn: Anaximander and the Origins of Greek Cosmology.

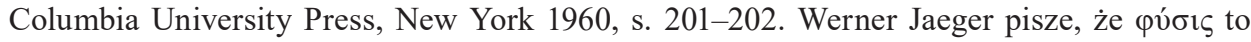
akt, ,proces rozwoju i powstawania; oto dlaczego Grecy często stosują je z dopełniaczem,

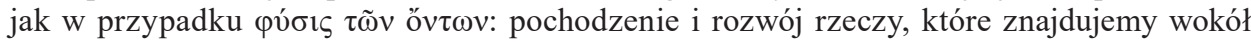
nas. Jednakże obejmuje ono również źródło ich powstawania [...], rzeczywistość leżącą 
Naturę tworzyło nie tylko to, co się porusza, lecz także to, dlaczego się porusza, zasada powstawania i wzrostu wszystkiego. Wszystko, co naturalne, miało „z siebie” zasadę swojego powstawania, w odróżnieniu od wytworów ludzkich: „żaden z nich bowiem nie ma w sobie zasady swego własnego

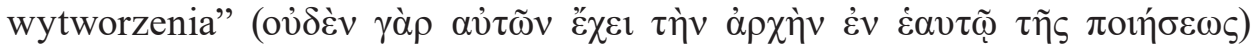
(Arystoteles, Fizyka 192b28-29, przeł. K. Leśniak). Bycie natury nie oznaczało jakiejś opozycji do powstawania, było raczej z nim scalone, jako coś samo z siebie żywego, dążącego do wzrostu, a jednocześnie niezależnie istniejącego, zawierającego realną zasadę organizującą całość, stałe, aktywne źródło wraz ze swoją konsekwencją, czyli procesem wzrostu, rozwoju ${ }^{38}$. Pytanie o istnienie natury byłoby tu bezsensowne: to, że natura istnieje sama z siebie, podobnie jak przedmioty, które są jej przejawem, było oczywiste (zob. Arystoteles, Fizyka 193a3-6) ${ }^{39}$. Natura to całość istniejąca, począwszy od aktywnego pryncypium, przez proces rozwoju, aż po skończony rezultat w postaci całego porządku świata ${ }^{40}$.

u podstaw rzeczy naszego doświadczenia”. W. Jaeger: Teologia wczesnych filozofów greckich. Przeł. J. Wocial. Wydawnictwo Homini, Kraków 2007, s. 52-53. Arthur Lovejoy

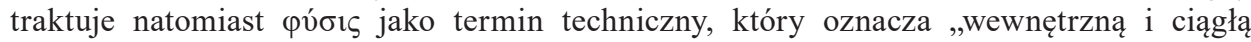
jakościową konstytucję” lub, mówiąc bardziej kolokwialnie, „to, czym rzeczy naprawdę są". A.O. Lovejoy: The Meaning of $\Phi v \sigma l \varsigma$ in the Greek Physiologers. „The Philosophical Review" 1909, vol. 18, no. 4, s. 376. https://doi.org/10.2307/2177774.

${ }_{38}$ Zob. G.S. Kirk: Heraclitus: The Cosmic Fragments. Cambridge University Press, Cambridge 1975, s. 42, 228, 230. Juliusz Domański również podkreśla dwa, przeciwstawne,

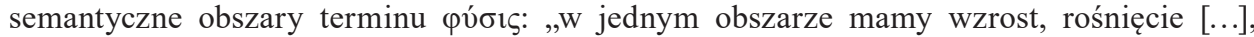
ogólnie rzecz biorąc, zmienność, dzianie się, proces; w drugim obszarze natomiast - stałość, regularność, nieprzypadkowość owej zmienności i owego procesu, a nade wszystko pierwotną czy docelową jedność i - mimo zmienności - tożsamość tego, co wzrostowi i rozwojowi, powstawaniu czy rozkładowi (lub unicestwieniu), czyli zmianie, podlega. Można powiedzieć, że dzięki tym swoim konotacjom jest to dla Greków stałość w zmienności, przemiana $\mathrm{i}$ jednocześnie trwanie w tożsamości, a w dalszej konsekwencji wielość i jedność zarazem, jedność w wielości”. J. Domański: Metafizyka Arystotelesowa..., s. 21-22. Wydaje się - pisze też Francis Cornford - „że jesteśmy w stanie wyróżnić dwie główne kategorie, wokół których różne sensy mogą być zgrupowane: statyczną i dynamiczną. Pojmowana statycznie Natura to system wszystkich zjawisk w czasie i przestrzeni, suma wszystkich istniejących rzeczy; a »naturą« rzeczy jest jej konstytucja, struktura, esencja. Ale nigdy nie straciła swojej drugiej, dynamicznej strony - znaczenia siły, pierwotnej, aktywnej, źródłowej energii - sensu, który, jak jego pochodzenie pokazuje, jest pierwotny". F.M. Cornford: From Religion to Philosophy. A Study in the Origins of Western Speculation. Princeton University Press, Princeton 1991, s. 73.

${ }^{39}$ Kiedy presokratycy zadawali pytanie: „czym jest natura?” - podkreśla Collingwood mieli na myśli pytanie: „z czego rzeczy są zrobione?”, a nie: „jakiego rodzaju rzeczy istnieją w świecie natury?”, jak by zadali je współcześni. R.G. Collingwood: The Idea of the Nature..., s. 43.

${ }^{40}$ Zob. G. Naddaf: The Greek Concept of Nature..., s. 20. 
W ramach podsumowania można powiedzieć, że po pierwsze, natura ( $\varphi v ́ \sigma ı \varsigma)$ oznaczała coś pierwotnego, źródłowego względem tego, co wtórne, względem wyłaniających się nieustanie przedmiotów odbieranych zmysłami. Po drugie, jest czymś realnym oraz autonomicznym i samoistnym, wyłania się niejako sama z siebie, nie jest jak dzieła, które są zrobione i wymyślone przez człowieka ${ }^{41}$. Po trzecie, stanowi istotę, esencję wszystkiego, de facto do natury można sprowadzić, „Zwinąć” całą doświadczaną zmysłami rzeczywistość. Natura stanowi więc przedmiot dociekań, który wyjaśnia cały różnorodny i zmysłowy świat. Po czwarte, jest podstawą ${ }^{42}$ - konstytuuje wewnętrznie wszystkie przedmioty naturalne, w tym ziemię i morza, rośliny

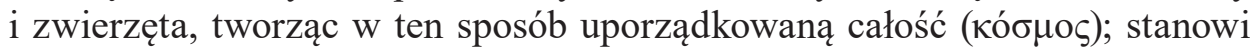
realny budulec (pratworzywo) wszystkiego, a przede wszystkim strukturę i immanentne prawo rządzące wszystkim oraz aktywną zasadę ruchu i rozwoju, powstawania i ginięcia, przenika wszystko, „płynie” w każdej roślinie i zwierzęciu, a wszystko, łącznie z bogami, jest naturze podporządkowane. Po piąte, natura ma charakter całościowy, to całość świata naturalnego, a w zasadzie cały proces powstawania świata, ze wskazaniem na jego pier-

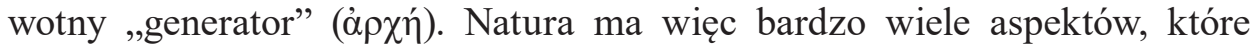
będą dopiero wydobyte $\mathrm{w}$ różnych teoriach filozoficznych, między innymi tych, w których znaczenia nabiera termin „byt”.

\section{Byt}

U samych początków filozofia określiła temat swoich dociekań: wszyst-

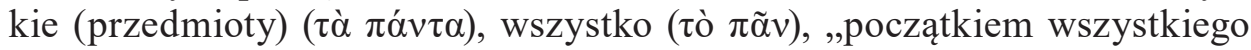

${ }^{41}$ Pojęcie natury, podkreśla Olof Gigon, oznacza „prawdziwą realność, przeciwstawioną temu, co wymyślone, domniemane, pozorne, rozdzielone na elementy przypadkowe. W każdym razie dąży do pierwotności - przeciw wtórności”. O. Gigon: Główne problemy filozofii starożytnej. Przeł. P. Domański. Polska Akademia Nauk, Instytut Filozofii i Socjologii, Warszawa 1996, s. 113. W podsumowaniu rozumienia tego pojęcia Gigon pisze: „Pojęcie natury w ogóle jako doskonałości, której nie mogą wytworzyć ani bogowie, ani ludzie, bo ona jest »z siebie«, jest tak gruntownie greckie jak chyba żadne inne". Ibidem, s. 117.

${ }^{42}$ Słowo „podstawa” jest tu użyte w szerokim sensie, choć można by dodać „bytowa”, ale już nie „substancjalna”, by nie wprowadzać ukutej później terminologii. Janina Gajda podkreśla, że arché dla pierwszych filozofów posiadała „status bytu i to bytu pierwszego in ordine essendi". J. Gajda: Filozofia przedsokratejska. Wydawnictwo Naukowe PWN, Warszawa 2007, s. 67. 


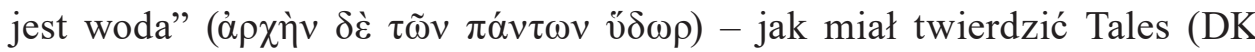
11 A 1, 27). Filozofia była od razu nastawiona maksymalistycznie, chciała wyjaśnić wszystko. Było to pierwsze rozumowe zebranie i ujęcie tego, czego część na co dzień jest doświadczana. Owo „wszystko” obejmowało nie tylko przedmioty bezpośrednio oglądane, lecz także te za wzgórzem, morzem, których zmysły nie były w stanie doświadczyć, lądy, do których Hellenowie jeszcze nie przybyli, a które rozum, jako pierwszy „odkrywca”, był w stanie w ten sposób „zdobyć”. Obejmowało też bogów, prawa i obowiązki, ogólnie wszystko, co jest dane lub może być dane. Oczywiście tacy presokratycy jak Tales nie poszukiwali tego wszystkiego, chodziło raczej o podanie zakresu, tematu, który filozofia miała podjąć. W tym ujęciu chodziło o to, by wszystko, tę całą wielką różnorodność i zmienność, zrozumieć. „Wszystko” to termin z jednej strony obejmujący bez wyjątków i pominięć, a $z$ drugiej wymagający jakiegoś dookreślenia lub z domyślnym dookreśleniem, bo nie miał obejmować na przykład wszystkich ludzkich narracji wypowiadanych w słowach i pieśniach. „Wszystko” oznaczało cały świat, wszystkie przedmioty, wszystkie zjawiska, bogów i ludzi - wszystko mieściło się w ramach jednej natury, miało jakieś jedno źródło.

We fragmentach presokratyków odnajdziemy słowo „wszystko" często $\mathrm{w}$ parze $\mathrm{z}$ czasownikiem ,być” lub jego znominalizowaną postacią. U Empedoklesa: „wszystko, co było, jest i będzie później” ( $\pi \alpha ́ v \theta$ '

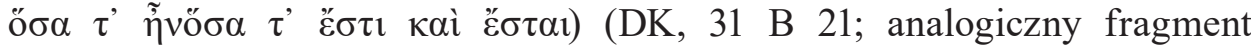
u Anaksagorasa: DK, 59 B 12, 10-12), które najczęściej będzie skrócone do

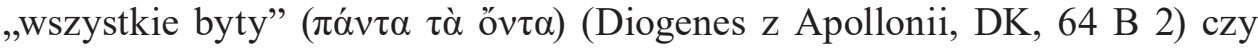
po prostu „byty” ( $\tau$ ò őv $\tau \alpha$ ), jak we fragmencie z Anaksymandra (DK, 12 A 9; uważa się, że to jedno z pierwszych filozoficznych użyć nominalizacji

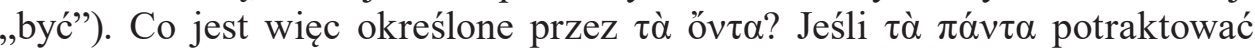
jako największą ekstensję słowa „wszystko”, to właściwie nic nie zostaje tu określone, jedynie wyznaczony jest maksymalny zakres. A wtedy słowa tego można użyć w odniesieniu do jakiegokolwiek przedmiotu. Liczba mnoga rzeczownika odsłownego i kontekst tych fragmentów wskazuje jednak na partykularne odniesienie do określonych elementów świata, o których jest coś do powiedzenia. W przytoczonych fragmentach mamy wymienione byty, o jakie chodzi: drzewa, ludzie, ptaki, a także bogowie (Empedokles), pierwotne elementy, jak wilgotne i suche, gorące i zimne (Anaksagoras), ziemia i woda, powietrze i ogień (Diogenes). Chodzi więc o wszystkie zjawiska i byty świata, które w nim można wyróżnić jako odrębne całości czy jednostki. Co mają z sobą wspólnego, prócz tego, że mogą zostać wyodrębnione? Wszystkie te byty są obecne $\mathrm{w}$ świecie, realnie $\mathrm{w}$ nim

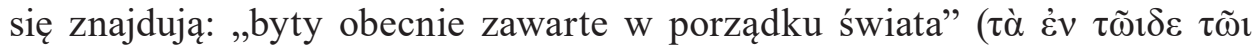




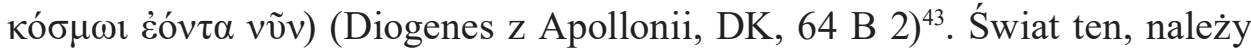
podkreślić, był rozumiany jako realnie istniejący, stąd powiązanie jakiegoś bytu / jakichś bytów z jego/ich miejscem lub obecnością domyślnie było jednoznaczne $\mathrm{z}$ podkreśleniem realnego istnienia bytu/bytów w tym świecie. Grecki imiesłów znaczy tu więc 'być w świecie, znajdować się, być obecnym' (co jest podkreślone przez vṽv - 'teraz'); jeśli weźmiemy pod uwagę nominalizację ( $\tau \grave{\alpha})$ czasownika „być”, będą to 'byty znajdujące się, obecne, składające się na świat ${ }^{44}$.

Zauważmy, że analogiczną formułę spotykamy w literaturze przedfilozo-

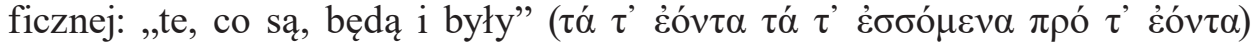
(Homer, Iliada, I, 70; Hezjod, Narodziny bogów 38). Grecki imiesłów zdaje się tutaj oznaczać określone wydarzenia, które zna wróżbita lub muzyk -

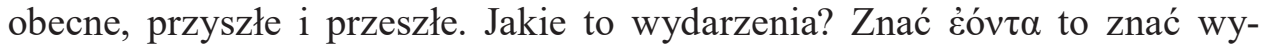
darzenia i okoliczności mające znaczenie, które są istotne dla znającego je. Są to bowiem wydarzenia nieprzypadkowe, a ich nieprzypadkowość wynika ze znajomości „drugiego planu”, z wiedzy o zamiarach i rozkazach bogów, którzy determinują bieg wydarzeń, wpływając zarazem na losy ludzi w nich

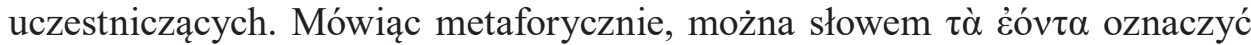
miejsce spotkania bogów z ludźmi: to, co jest, będzie i było, dla ludzi jest koniecznością, a dla bogów wyrazem ich boskiej mocy i woli, którą może poznać człowiek i która staje się ważna dla jego losów. To wydarzenia mające miejsce $\mathrm{w}$ świecie, ale przede wszystkim boską genealogię. Użyta formuła zdaje się jednak nie wprowadzać podmiotu, bo cała historia będzie

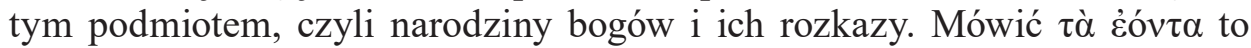
objawiać istotną rzeczywistość (wydarzenia), odsłaniać przed słuchaczami genealogię bóstw i wydarzenia $\mathrm{z}$ woli bogów inspirowane. Natchnienie pozwoli zajrzeć pod powierzchnię zwykłego biegu rzeczy i dostrzec jego przy-

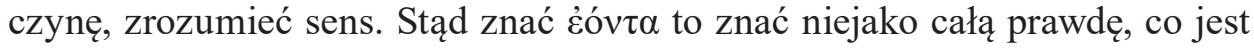

${ }^{43}$ Podobne użycie u Hipokratesa, De Natura Hominis 7, 39-40: „wszystkie byty, które

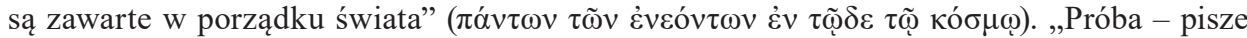
Charles H. Kahn - dania unifikacyjnego wyjaśnienia naturalnego uniwersum jako całości powoduje, że potrzebujemy terminologii desygnującej wszystkie czynniki i zawartość porządku świata, jakiekolwiek one mogą być. Liczba mnoga zaimka nijakiego $\pi \alpha ́ v \tau \alpha$ »wszystko«, "wszystkie rzeczy« najczęściej będzie wystarczała. Ale kiedy jest potrzebny pełny termin na określenie fizycznej obecności i rzeczywistości tych jednostek [reality of

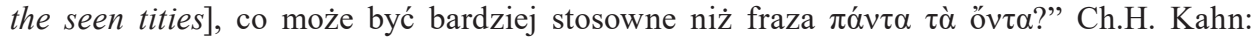
The Verb „Be”..., s. 456.

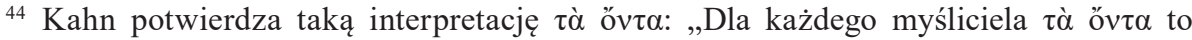
zawartość i części składowe światowego porządku [the contents and constituents of the

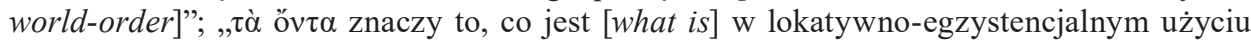
عìuí, rzeczy, które istnieją, rzeczy, które są obecne lub które gdzieś się znajdują [which are to be found somewhere], na przykład »rzeczy, które są obecne w tym porządku świata« $\tau \grave{\alpha}$

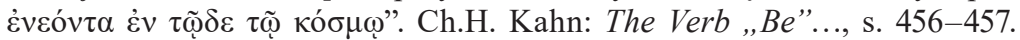


oddawane poprzez formułę „to, co jest, będzie i było”, czyli pełną historię, nie jako następujące po sobie fakty, ale ich sens, ich przyczynę. Znać byty (wydarzenia) to znać fakty od strony tego, co je tłumaczy, a nie je same.

Analogicznie możemy czytać myśl pierwszych filozofów. Przenoszą oni

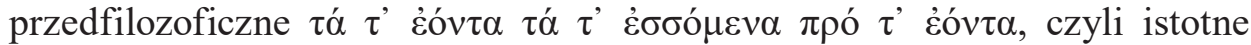
wydarzenia mające boską genealogię, w kontekst filozoficzny. Wydarzenia

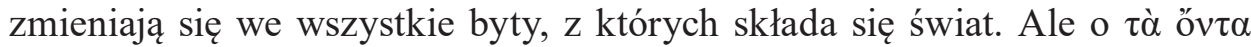

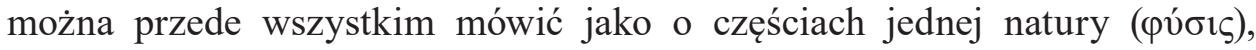
zebranych i odniesionych do jednej zasady i początku (å $\chi \eta \eta)$. Byty - według Anaksymandra - powstają w pierwotnej naturze i do niej powracają

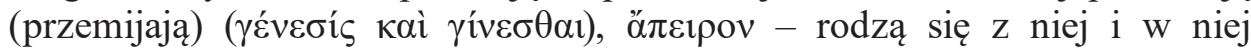
umierają ${ }^{45}$. Stopniowo, zapewne pod wpływem eleackich argumentów przeciw powstawaniu, akcent $\mathrm{w}$ pojmowaniu natury zostanie przeniesiony $\mathrm{z}$ powstawania na stałość, model wyjaśniania genetycznego (,x pochodzi z Y”) będzie ewoluował w model wyjaśniania składnikowego (,x składa się z Y”, „x jest zrobione z Y" ${ }^{46}$, czyli wyjaśniania opartego na istotnych i stałych składnikach, z których są złożone wszystkie przedmioty, czy tworzywie, z którego są zrobione. Te pierwotne elementy to na przykład „cztery korzenie wszystkiego” (Empedokles) czy „niezliczone nasiona” (Anaksagoras) ${ }^{47}$.

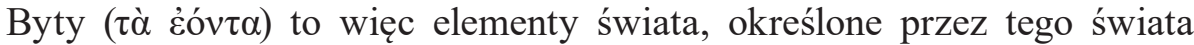
naturę. Są one wzięte niejako w całości, wraz ze swoim czynnikiem wyjaśniającym i porządkującym, tak jak w wyjaśnianiu mitologicznym wydarzenia mające boską genealogię. Tu byty wywodzą się z czegoś prostszego,

${ }^{4}$ Anaksymander „Twierdził, że zasadą bytów jest jakaś natura apeiron, z której powstają nieba i w nich porządek" (oṽ

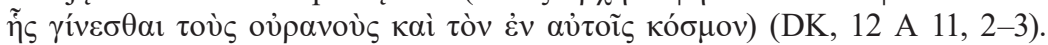

${ }^{46} \mathrm{Za} x$ możemy podstawić wszystkie przedmioty lub jakiś przedmiot, a za $Y$ naturę wyjaśniającą, czyli na przykład apeiron, powietrze - stąd duża litera, jak w nazwie własnej. Warto też wspomnieć o stworzonym przez pitagorejczyków modelu strukturalnym, który

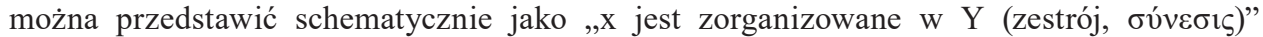
lub „x jest organizowane przez Y (harmonię, $\alpha \rho \mu o v i ́ \alpha) ”$, oraz modelu ontycznym, od czasów Parmenidesa: „x jest (w sobie) X” lub „x jest (naprawdę) Y”, gdzie X, Y oznaczają tożsamość natury, jej byt. Julius Moravcsik ogranicza się do trzech etapów i trzech głównych modeli wyjaśniających: wyjaśniania w terminach pochodzenia (origin) (,,x zapoczątkowuje y”), surowca (stuff) (,x jest zrobiony z y”) i atrybutów (attribute) (orzekanych o danym przedmiocie). M. Moravcsik: Heraclitean Concepts..., s. 135-138. Podobnie Alfred Gawroński pisze o trzech „modelach wyjaśniania”, jakimi dysponuje człowiek: modelu historyczno-kosmologicznym (diachronicznym), fizykalno-składnikowym i logicznym modelu podmiotowo-orzecznikowym (synchronicznym). A. Gawroński: Rewolucja lingwistyczna presokratyków..., s. 77-78.

${ }^{47}$ „Żadna rzecz ani nie powstaje, ani nie ginie, lecz składa się z istniejących rzeczy

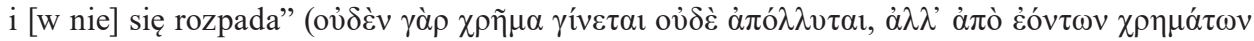

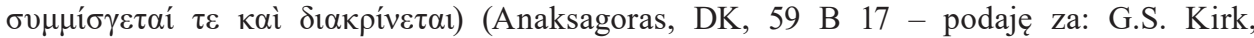
J.E. Raven, M. Schofield: Filozofia przedsokratejska..., s. 354). 
bardziej podstawowego, jak dom z kamieni połączonych w jakąs strukturę lub podporządkowanych jakiemuś prawu. A zatem również te bardziej pierwotne elementy, które wchodzą w skład przedmiotów, to byty, nawet „bardziej będące”, bo nie są tylko teraz, ale w całości czasu, zachowują się $\mathrm{w}$ nim, podczas gdy tamte, które są $\mathrm{z}$ nich zrobione, zmieniają się ${ }^{48}$. Bo ta wszechczasowość (teraźniejszość, przyszłość, przeszłość) w formule bytu („to, co jest, będzie i było”) oznaczać może właśnie z jednej strony to samo, co „wszystko”, pewien zakres przedmiotów, które mają zostać objęte, a z drugiej - że to, co wewnętrznie nimi rządzi, konstytuuje je w każdym czasie. Byty to nie przedmioty rozpatrywane same w sobie, ale partykularne części natury, które mają w sobie jej konstytucję. Są one od razu „zakorzenione", jak roślina z Iliady, jak grzyby wyrastające z jednej grzybni, stąd są. A umysł filozofa potrafi podać ich genezę lub ich pierwotne składniki, przeniknąć przez zmieniającą się i różnorodną zjawiskowość do „korzenia”, czyli natury. Byty to więc zarówno to, co powstaje z pierwotnych elementów natury i na nie się rozkłada, to wszystko, co (aktualnie) jest z nich skomponowane, jak i same te pierwotne elementy, które zawsze (w każdym czasie) zachowują swoją naturę.

Należy też zwrócić uwagę, że pierwotne elementy, jak gorące i zimne czy ziemia i powietrze, to składniki przedmiotu zmysłowego, ale jeśli zostaną wzięte same w sobie, to będą stanowić byty - czyli naturę rzeczy. Nie są to abstrakty, ogólne pojęcia orzekane o przedmiotach, ale realne istoty, konstytuujące je od wewnątrz. Jeśli jakieś byty są gorące, to nie oznacza, że przynależą one do klasy gorących, ale że przedmioty są tak zbudowane, mają taką naturę, która sprawia, że mogą oparzyć. Gorące to byty gorące, jak i natura gorąca ${ }^{49}$. Pierwsi filozofowie greccy nie rozróżniali podmiotu jakości i samej jakości - jakości konstytuują byty i jednocześnie są tymi bytami, istnieją jako byty. Presokratycy nie myśleli jeszcze w modelu podmiotowo-atrybutywnym - samoistnego podmiotu i przypisywanych mu niesamodzielnych cech. Mówiąc inaczej, ci wcześni filozofowie, podobnie jak

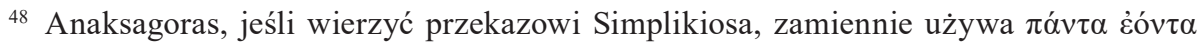

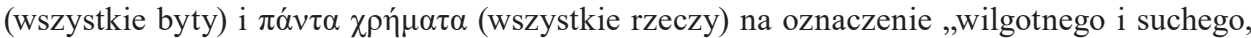
gorącego i zimnego, jasnego i ciemnego" ziemi i powietrza, a przede wszystkim niezli-

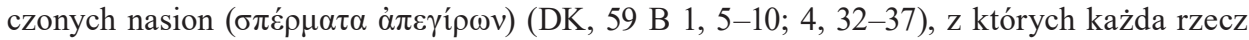
się składa i na które się rozkłada, łącznie z bytami (rzeczami), które są teraz wśród ludzi

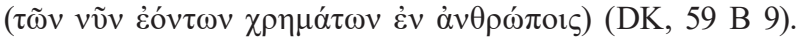

49 „Wcześniejsi myśliciele - wyjaśnia William Guthrie - nie odróżniali wyraźnie tego, co ma lub jest charakteryzowane przez jakość, od jakości samej. Dwuznaczność greckich idiomów (przedimek-plus-przymiotnik) ułatwiała pomylenie tych dwóch [znaczeń]: »gorące« (»the hot«) oznacza zarówno gorącą substancję [a hot substance], jak i gorąco jako jakość [the quality of heat]". W.K.C. Guthrie: A History of Greek Philosophy. Vol. 5: The Later Plato and the Academy. Cambridge University Press, Cambridge 1978, s. 138. 
później Platon, najczęściej traktowali „bez różnicy to, co obecnie rozróżnia się jako konotację (intensję) i denotację (ekstensję)" "50. Gorący na przykład kamień jest gorącym przedmiotem fizycznym, ale też ma właściwość gorąca, która się $\mathrm{w}$ nim przejawia. Ta właściwość jest też bytem, a nie tylko wyabstrahowaną cechą, buduje kamień w ten sposób, że kamień może się nagrzewać, tak jak ogień Heraklita - przekształcający się wedle praw logosu

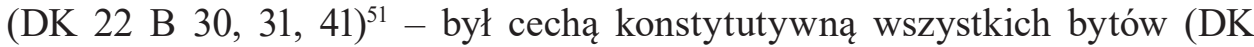
22 B 90, 126).

Powtórzmy: jeśli byty można traktować jako jednostkowe przedmioty zmysłowe, to są one zawsze wzięte wraz ze swoją naturą, która nie jest wprost dostępna zmysłom, ale poznawalna dzięki umysłowi. Natura to samoistne źródło i zasada wszystkiego, jest domyślnie niestworzona i realnie istnieje poza umysłem człowieka, stanowi podstawę porządku świata. Byt więc we wczesnej refleksji filozoficznej trzeba rozumieć w kontekście natury: to jej widzialny element, ale przede wszystkim stojący za nim niewidzialny pierwotny element.

Zestawmy teraz różne aspekty rozumienia bytu, które zostały tu określone. Po pierwsze, byt oznacza coś wydzielonego ze świata, jednostki czy całości, które można zidentyfikować. Stąd zwykle oddawany jest dystrybu-

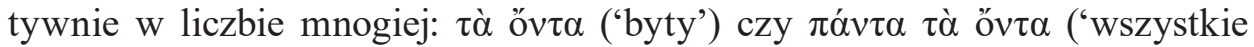
byty'), choć poprzez słowo „wszystkie” ( $\pi \alpha ́ v \tau \alpha)$ można to czytać też kolektywnie jako 'rzeczywistość'.

Po drugie, byt oznacza coś istniejącego niezależnie od człowieka i niestworzonego przez niego, stąd znajdującego się, obecnego w świecie oraz doń przynależnego. Nie oznacza stanu czy czynności, czyli samego istnienia lub realności, ale przedmioty, które ten stan posiadają.

Po trzecie, byt oznacza coś istniejącego i zarazem określonego, to znaczy znajdującego się w naturze i jednocześnie przez tę naturę określonego, konstytuowanego i wyjaśnianego. Być czymś i istnieć jest tu tym samym.

Po czwarte, byt oznacza zawsze powiązanie $\mathrm{z}$ naturą ( $(v \mathbf{\sigma} \sigma \varsigma)$, która sprawia, że poszczególne przedmioty mogą się w niej znajdować (istnieć) i przejawiać takie, a nie inne właściwości. Nie są to osadzone zewnętrznie w naturze „klocki”, ale byty wyrastające z natury, mają w niej „,ukorzenienie”, stały udział w jej „krwiobiegu”. „Będące” to znajdujące się w stanie powią-

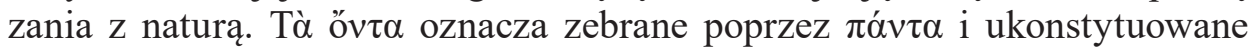
poprzez naturę, która czyni je dostępnymi, danymi, realnymi, mającymi takie a takie właściwości. Nie są to jednostki suwerenne, nie można ich rozpatry-

${ }^{50}$ L.M. de Rijk: Plato's Sophist..., s. 87, 264-265; Idem: Aristotle: Semantics and Ontology. Vol. 1: General Introduction. The Works on Logic. Brill, Leiden 2002, s. 725.

${ }_{51}$ Zob. K. Narecki: LOGOS we wczesnej myśli greckiej. Redakcja Wydawnictw KUL, Lublin 1999, s. 93. 
wać niezależnie od świata, w którym się znajdują. Tym, co mają wspólnego,

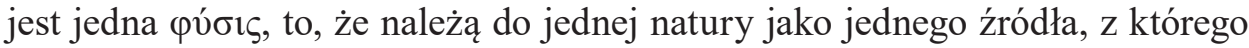
się wyłaniają, aktywnej zasady nimi rządzącej i esencji, do której można je sprowadzić. Stąd mogą zwać się bytami natury, jej elementami.

Po piąte, byt, jako element natury, to przejaw natury i sama ta natura. Oznacza więc zarówno całość zewnętrzną, dostępny zmysłami przedmiot (na przykład konkretne drzewo) wraz z jego wewnętrzną konstytucją, jak i samą tę wewnętrzną konstytucję, dostępną rozumem (na przykład atomy).

Po szóste, byty to istotne jakości, które powodują, że przedmioty przejawiają właśnie takie, a nie inne cechy; jednocześnie same te cechy tworzą suwerenne, pierwotne elementy, funkcjonujące pod ,powierzchnią” zjawisk.

\section{Podsumowanie}

Niektórzy współcześni badacze określają metafizykę jako identyfikowanie „natury i struktury wszystkiego, co jest”52, „filozoficzne badanie natury, konstytucji i struktury rzeczywistości” ${ }^{53}$ czy „badanie ostatecznej rzeczywistości" ${ }^{54}$. Z przedstawionych analiz wynika, że badania, jakie przeprowadzali pierwsi filozofowie, możemy określić identycznie - jako badania natury (istoty) świata, choć w ówczesnej refleksji nie oddzielano jeszcze fizyki od metafizyki ${ }^{55}$. Oczywiście już w starożytności badania natury rzeczy rozpoczęte przez pierwszych filozofów zostały skrytykowane przez Platona (zob. Fedon 96a-97b, Prawa 891c-892c) i Arystotelesa.

${ }_{52}$ M.J. Loux, T.M. Crisp: Metaphysics. A Contemporary Introduction. Routledge, New York 2017, s. XI.

53 The Cambridge Dictionary of Philosophy. Ed. R. Audi. Cambridge University Press, New York 1999, s. 563.

${ }^{54}$ P. van Inwagen: Metaphysics. Westview Press, Boulder 2015, s. 1.

55 „Punktem wyjścia dla myśli filozoficznej VI w. - pisał Werner Jaeger - stało się pytanie o początek, o physis wszystkiego, i ta problematyka nadała imię całemu temu prądowi umysłowemu i formom badawczym, które on stworzył. [...] Oczywista, że ten prąd umysłowy doprowadził z czasem do powstania nauki o przyrodzie, ale początkowo mieściła się ona bez reszty w ramach rozważań metafizycznych i stopniowo dopiero zdołała się usamodzielnić. W greckim pojęciu physis tworzą jeszcze niepodzielną całość zarówno pytanie o początek wszechrzeczy, które każe wyjść poza zakres spraw danych nam w doświadczeniu zmysłowym, jak i próba ogarnięcia tego wszystkiego, co z tego praźródła powstało i obecnie istnieje (ta onta), za pomocą zbierania konkretnych danych doświadczenia (historie)". W. Jaeger: Paideia..., s. 233. 
Zakwalifikowano je do badań nad - jak powiedzielibyśmy współcześnie przyrodą oraz jej powstaniem i mechanizmami rozwoju. Należy jednak zauważyć, że w tych wczesnych rozważaniach była mowa o wielu różnych aspektach natury, przede wszystkim zmianie i stałości, które później zostały - w nowych modelach wyjaśniania i określonych teoriach - rozdzielone. Stąd Platon uważa, że badania nad naturą nie dotyczą bytów stałych ( $\tau$ ò

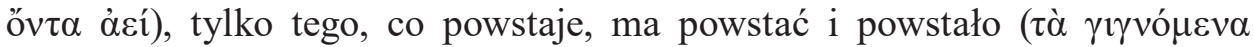

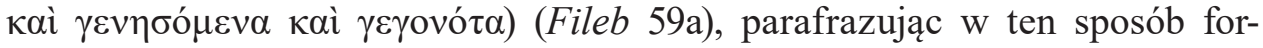

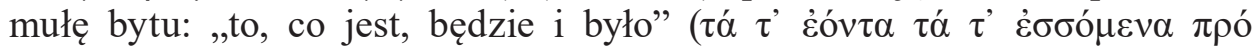

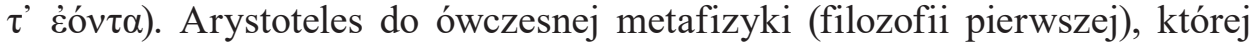
przedmiotem był stały i wieczny byt, nie zaliczał pierwszych filozofów (prócz eleatów), ponieważ traktował ich jako fizyków ( mujących się przyrodą ( $\varphi v ́ \sigma 1 \varsigma$ ), tu rozumianą jako byt w ruchu (Metafizyka 1026a, Fizyka 184b-185a) ${ }^{56}$. Z przedstawionych analiz wynika, że pojęcie natury obejmowało $\mathrm{w}$ myśli pierwszych filozofów to, co implicite było też stałe lub wieczne. Pomimo że modele wyjaśniania genetycznego oraz poszukiwania pratworzywa świata jako podstawy mogły być powodem do uznania owych filozofów za ówczesnych przyrodników czy materialistów ${ }^{57}$, natura - jak starano się pokazać - funkcjonowała w o wiele bogatszym sensie niż dostępna zmysłami przyroda czy aspekt budulca, a kierunek badań był wyraźnie spekulatywny i metafizyczny ${ }^{58}$. W późniejszej myśli zadanie

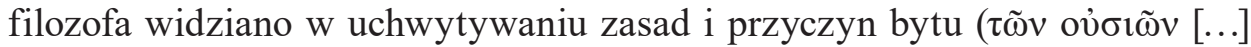

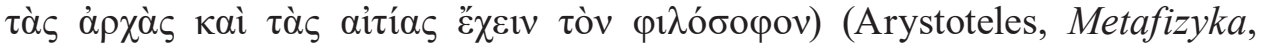

${ }^{56}$ „Arystotelesowe - objaśnia Juliusz Domański - rozróżnienie tego, co »z natury«, i tego, co tryb »natury« przekracza, niewiele ma wspólnego z zakodowaną jakoś w myśleniu europejskim ostrą granicą dzielącą strefę »natury« od strefy »nadnatury«, tak jak ją ukonstytuowało chrześcijaństwo. Przyjmując za wyróżnik substancji przekraczającej tryb natury niezmienność tej substancji, Arystoteles pozostawał nadal nie tylko bardzo blisko wypracowanego przez swoich poprzedników w filozofii pojęcia physis, ale też - pod pewnym względem - ciągle w jego obrębie. Nieruchomość bowiem, czyli niezmienność, a także implikowana przez nią jedność, były w pojęcie natury wintegrowane od początku greckich dociekań filozoficznych, a nawet na długo jeszcze przed ich początkiem. Tkwiły one w samej pierwotnej nazwie »natury« i w wyobrażeniu jej pierwotnego desygnatu. Pierwsi filozofowie budowali to pojęcie w ścisłym związku z pytaniem o treść innego pojęcia, również stale towarzyszącego metafilozoficznej refleksji Arystotelesa, o treść po-

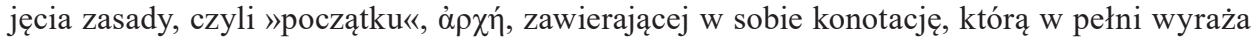
jeszcze inne ciągle obecne w interesujących nas tekstach Arystotelesa pojęcie sprawstwa, czyli przyczyny, aiıía”. J. Domański: Metafizyka Arystotelesowa..., s. 18.

${ }^{57}$ Zob. K. Leśniak: Materialiści greccy w epoce przedsokratejskiej. Wiedza Powszechna, Warszawa 1972, s. 21: filozofia jońskiej szkoły „była przyrodnicza, materialistyczna, ateistyczna".

${ }^{58}$ Zob. M. Gentile: La metafisica presofistica. Petite Plaisance, Pistoia 2006 (1st ed. Padova 1939). 
1003b18-19), czyli rozważaniu natury wszelkiego bytu (

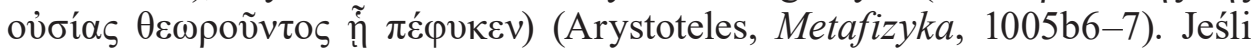
nie to samo, to przynajmniej podobnie można powiedzieć o badaniach presokratyków: choć nie operowali oni jeszcze ściśle technicznymi terminami „zasada” lub „przyczyna”, rozumienie przez tych filozofów natury zmierzało dokładnie w tym kierunku - poszukiwano (ostatecznej) natury jako podstawy zmysłowej przyrody.

Należy też podkreślić, że pytanie o naturę nie sprowadzało się tylko do poszukiwania jej klasyfikującego umysłowego pojęcia, przede wszystkim próbowano wskazać jego desygnat: czym jest ta natura, co nią jest. Chodziło o zbadanie i odkrycie przedmiotu, który jest zdolny do nieustannego „rodzenia” wszystkiego, czego można doświadczyć. Oczywiście poszukiwanie esencji świata wśród wyróżnionych jakości, jak ciepłe i zimne czy woda i powietrze, zostało zdyskredytowane $\mathrm{w}$ teoriach następców, a dziś ma znaczenie tylko historyczne. Natura rzeczy jednak, rozumiana jako istotne jakości tkwiące pod powierzchnią zjawisk, to nie z góry skazane na niepowodzenie poszukiwanie shipostazowanych pojęć ukrytych w ,rzeczach”59, ale kierunek myślenia i poszukiwanie uzasadnienia, które ma pozwolić zrozumieć, dlaczego coś jest takie-a-takie i dlaczego w ogóle jest. Pierwsze odpowiedzi wczesnych filozofów wskazywały nie tylko na „prażywioł”, jak woda (Tales), lecz także na prawa logosu (Heraklit) czy strukturę, którą opisuje matematyka (pitagorejczycy).

Filozoficzna refleksja, która zrodziła się w starożytnej Grecji, zasymilowała generalne pojęcie świata jako niezależnej od człowieka całości, w której wydarzenia i dostępne zmysłami przedmioty były podporządkowane boskim siłom i prawom. W toku filozoficznych badań świat zyskał miano

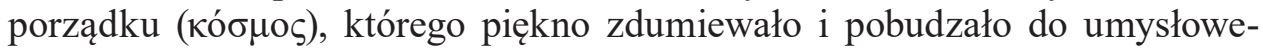
go ujęcia, czyli poszukiwania racjonalnych podstaw i zasad w pełni świat wyjaśniających. To z tymi podstawami i zasadami należy głównie wiązać pojęcie natury ( $\varphi v ́ \sigma ı \zeta)$ - natura rzeczy to realna podstawa, zasada przedmiotów i ich właściwości. Natura była pojęta jako autonomiczna i samoistna, jako wyłaniająca się sama z siebie i stanowiąca wewnętrzną konstytucję oraz prawo wszystkiego. Uznawano, że natura istnieje niezależnie od człowieka i jednocześnie jest budulcem oraz nadaje kształt, strukturę, prawidła, ruch, rozwój wszystkim przedmiotom zmysłowo dostępnym. Stanowi więc realną podstawę wszystkich bytów, jak u Heraklita, w którego ujęciu jest wiecznie zmieniającym się według praw logosu ogniem, z niego zaś byty się wywodzą lub nim w istocie są, czyli do niego jako esencji mogą zostać sprowadzone i w nim wyjaśnione.

${ }^{59}$ Zob. M. Heller: Filozofia i wszechświat. Towarzystwo Autorów i Wydawców Prac Naukowych Universitas, Kraków 2008, s. 129-136. 
Natura rzeczy fundowała to, czym przedmioty są i że są, to jest znajdują się aktualnie w świecie, są w nim obecne jako niezależne od człowieka, choć zależne od swojego wewnętrznego „fundatora”. „Byty”, określenie, którym zaczęto operować we wczesnej filozofii greckiej, można oddać poprzez 'elementy natury'. Taka interpretacja zakłada, że dla rozumienia bytów kluczowe jest rozumienie natury, do której zarówno czasownik „być”, jak i jego nominalizacje odsyłały. Być to znajdować się (poza umysłem) w świecie, wywodzić się lub składać się z pierwotnej, samoistnej natury, a co za tym idzie, być przez nią określonym, mieć dzięki niej takie, a nie inne właściwości. Byt natomiast to realny element natury, rozumiany dystrybutywnie jako, po pierwsze, wszystkie przedmioty dostępne zmysłami, zawierające w sobie konstytuującą je naturę i dlatego mogące w ogóle pojawić się jako na przykład fizyczne drzewa (rozumienie zewnętrzne); po drugie, jako pierwotne części natury, istotne jakości konstytuujące od wewnątrz te byty, jak powietrze (Anaksymenes) czy atomy (Demokryt) (rozumienie wewnętrzne). Byt to przejaw natury i ona sama, to taka lub inna postać natury, mająca cechy samoistności i nadawania właściwości. To „zdwojenie”, tu zjednoczone słowem „natura”, stało się później punktem rozejścia się fizyki i metafizyki w refleksji takich filozofów jak Tales czy Heraklit funkcjonowało w ramach jednej nauki o naturze, której zakres był zbliżony do zakresu nauki z pism

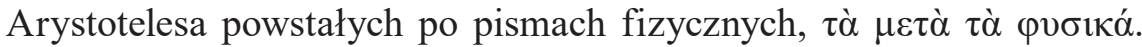

\section{Bibliografia}

Albert K.: O Platońskim pojęciu filozofii. Przeł. J. Drewnowski. Polska Akademia Nauk, Instytut Filozofii i Socjologii, Warszawa 1991.

Arendt H.: Myślenie. Przeł. H. Buczyńska-Garewicz. Spółdzielnia Wydawnicza „Czytelnik”, Warszawa 1991.

Aristotelis Physica. Ed. W.D. Ross. Oxford University Press, Oxford 1950.

Arystoteles: Dzieła wszystkie. T. 2: Fizyka; O niebie; O powstawaniu i niszczeniu; Meteorologika; O świecie; Metafizyka. Przeł. K. Leśniak. Państwowe Wydawnictwo Naukowe, Warszawa 1990.

Arystoteles: Metafizyka. Tekst polski oprac. M.A. Krąpiec, A. Maryniarczyk na podstawie tłum. T. Żeleźnika. Redakcja Wydawnictw KUL, Lublin 1996.

Beardslee J.W.: The Use of PHYSIS in Fifth-Century Greek Literature. The University of Chicago Press, Chicago 1918. 
Benveniste E.: Noms d'agent et noms d'action en indo-européen. Klincksieck, Paris 1948.

Benveniste E.: Problèmes de linguistique générale. Vol. 1. Gallimard, Paris 1966.

Buck C.D.: A Dictionary of Selected Synonyms in the Principal Indo-European Languages. A Contribution to the History of Ideas. University of Chicago Press, Chicago 1949.

Bultmann R.: Zur Geschichte der Lichtsymbolik im Altertum. „Philologus Zeitschrift für antike Literatur und ihre Rezeption" 1948, vol. 97, s. 1-36.

Burnet J.: Greek Philosophy. Thales to Plato. MacMillan, London 1924.

The Cambridge Dictionary of Philosophy. Ed. R. Audi. Cambridge University Press, New York 1999.

Collingwood R.G.: The Idea of the Nature. Clarendon Press, Oxford 1945.

Cornford F.M.: From Religion to Philosophy. A Study in the Origins of Western Speculation. Princeton University Press, Princeton 1991.

Curtius G.: Grundzüge der Griechische Etymologie. Teubner, Leipzig 1869.

Domański J.: Metafizyka Arystotelesowa i fizyka pierwszych filozofów. (Uwagi $o$ nazwie, pojęciu i przedmiocie metafizyki). „Archiwum Historii Filozofii i Myśli Społecznej" 1991, nr 36, s. 5-24. Pobrano z: http://old.archidei.ifispan. $\mathrm{pl} / \mathrm{pdf} / 41$ ahf0001_36_domanski.pdf [12.06.2021].

Die Fragmente der Vorsokratiker. Eds. H. Diels, W. Kranz. Vol. 1-3. Weidmann, Zürich-Hildesheim 2014.

Gajda J.: Filozofia przedsokratejska. Wydawnictwo Naukowe PWN, Warszawa 2007.

Gawroński A.: Rewolucja lingwistyczna presokratyków. Język a rzeczywistość (11). „Znak” 1992, nr 440 (1), s. 76-85.

Gentile M.: La metafisica presofistica. Petite Plaisance, Pistoia 2006 (1st ed. Padova 1939).

Gigon O.: Główne problemy filozofii starożytnej. Przeł. P. Domański. Polska Akademia Nauk, Instytut Filozofii i Socjologii, Warszawa 1996.

Gilson E.: Byt $i$ istota. Przeł. P. Lubicz, J. Nowak. Instytut Wydawniczy PAX, Warszawa 1963.

Guthrie W.K.C.: A History of Greek Philosophy. Vol. 5: The Later Plato and the Academy. Cambridge University Press, Cambridge 1978.

Havelock E.A.: The Early History of the Verb „to Be”. W: Idem: The Greek Concept of Justice. From Its Shadow in Homer to Its Substance in Plato. Harvard University Press, Cambridge 1978, s. 233-248.

Heidegger M.: Wprowadzenie do metafizyki. Przeł. R. Marszałek. Wydawnictwo KR, Warszawa 2000.

Heller M.: Filozofia $i$ wszechświat. Towarzystwo Autorów i Wydawców Prac Naukowych Universitas, Kraków 2008.

Heubeck A., West S., Hainsworth J.B.: A Commentary on Homer's Odyssey. Vol. 2. Clarendon Press, Oxford 1988.

Inwagen P. van: Metaphysics. Westview Press, Boulder 2015.

Jaeger W.: Paideia. Formowanie człowieka greckiego. Przeł. M. Plezia, H. Bednarek. Fundacja Aletheia, Warszawa 2001. 
Jaeger W.: Teologia wczesnych filozofów greckich. Przeł. J. Wocial. Wydawnictwo Homini, Kraków 2007.

Kahn Ch.H.: Anaximander and the Origins of Greek Cosmology. Columbia University Press, New York 1960.

Kahn Ch.H.: The Verb „Be” in Ancient Greek. D. Reidel Publishing Company, Dordrecht-Boston 1973.

Kirk G.S.: Heraclitus: The Cosmic Fragments. Cambridge University Press, Cambridge 1975.

Kirk G.S., Raven J.E., Schofield M.: Filozofia przedsokratejska. Studium krytyczne $z$ wybranymi tekstami. Przeł. J. Lang. Wydawnictwo Naukowe PWN-Axis, Warszawa 1999.

Kubok D.: Problem apeiron i peras w filozofii przedsokratejskiej. Uniwersytet Śląski w Katowicach, Instytut Filozofii, Katowice 1998.

Leśniak K.: Materialiści greccy w epoce przedsokratejskiej. Wiedza Powszechna, Warszawa 1972.

Lloyd G.E.R.: Nauka grecka od Talesa do Arystotelesa. Przeł. J. Lesiński. Prószyński i S-ka, Warszawa 1998.

Loux M.J., Crisp T.M.: Metaphysics. A Contemporary Introduction. Routledge, New York 2017.

Lovejoy A.O.: The Meaning of $\Phi v \sigma l \varsigma$ in the Greek Physiologers. „The Philosophical Review" 1909, vol. 18, no. 4, s. 369-383. https://doi.org/10.2307/2177774.

Lyons J.: Wstęp do językoznawstwa. Przeł. K. Bogacki. Państwowe Wydawnictwo Naukowe, Warszawa 1975.

Moravcsik M.: Heraclitean Concepts and Explanations. W: Language and Thought in Early Greek Philosophy. Ed. K. Robb. The Hegeler Institute, La Salle, Illinois 1983, s. 134-152.

Naddaf G.: The Greek Concept of Nature. State University of New York Press, New York 2005.

Narecki K.: LOGOS we wczesnej myśli greckiej. Redakcja Wydawnictw KUL, Lublin 1999.

Otto W.F.: Dionizos. Mit i kult. Przeł. J. Korpanty. Wydawnictwo Naukowe Sub Lupa, Warszawa 2020.

Otto W.F.: Die Götter Griechenlands. Das Bild des Göttlichen im Spiegel des griechischen Geistes. Friedrich Cohen, Bonn 1929.

Perseus Digital Library. Ed. G.R. Crane. www.perseus.tufts.edu [dostęp: 23.07.2021].

Reale G.: Historia filozofii starożytnej. T. 1: Od początków do Sokratesa. Przeł. E.I. Zieliński. Redakcja Wydawnictw KUL, Lublin 1994.

Rijk L.M. de: Aristotle: Semantics and Ontology. Vol. 1: General Introduction. The Works on Logic. Brill, Leiden 2002.

Rijk L.M. de: Plato's Sophist. A Philosophical Commentary. North-Holland Publishing Company, Amsterdam 1986.

Rybowska J.: Zbożność i bezbożność w kulturze Greków. Wydawnictwo Uniwersytetu Łódzkiego, Łódź 2017.

Schrödinger E.: Przyroda i Grecy. Nauki przyrodnicze $i$ humanistyczne. Przeł. K. Napiórkowski. Wydawnictwo IFiS PAN, Warszawa 2017. 
Stróżewski W.: Pytania o ,arche”. W: Idem: Istnienie $i$ sens. Wydawnictwo Znak, Kraków 1994, s. 7-48.

Swieżawski S.: Byt. Zagadnienia metafizyki tomistycznej. Wydawnictwo Znak, Kraków 1999.

Vernant J.P.: Źródła myśli greckiej. Przeł. J. Szacki. Wydawnictwo słowo / obraz terytoria, Gdańsk 1996.

Wesoły M.: Heraklit $w$ świetle najnowszych badań. „Studia Filozoficzne” 1989, nr 7-8, s. 33-47.

Zieliński T.: Religia starożytnej Grecji. Zarys ogólny. Religia hellenizmu. Zakład Narodowy im. Ossolińskich - Wydawnictwo, Wrocław 1991.

Rafal Katamay - doktor filozofii, wykładowca i kierownik Katedry Nauk Społecznych w Wyższej Szkole Zarządzania Ochroną Pracy w Katowicach. Zajmuje się wybranymi zagadnieniami z obszaru metafizyki/ontologii, historii filozofii starożytnej, etyki, jak problem bytu (w szczególności w filozofii Platona), zła (w kontekście teizmu chrześcijańskiego), dobra oraz kwestiami metodologicznymi związanymi z racjonalnym myśleniem. Autor rozprawy doktorskiej Ontologia Platońskiego „, Sofisty”. 